
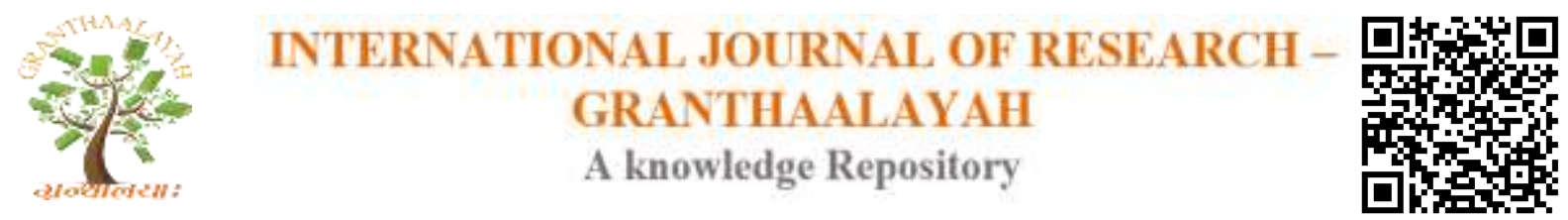

Social

\title{
THE IMPACT OF ISLAM ON SOCIO-POLITICAL STRUCTURE OF MANDARA SULTANATE: AN OVERVIEW
}

\author{
Dr Dani Mamman *1, Dr S. Y. Ibrahim ${ }^{2}$ \\ ${ }^{*}$ Department of Arabic and Islamic Studies, University of Maiduguri, Nigeria \\ ${ }^{2}$ Department of Public Administration, University of Maiduguri, Nigeria
}

\begin{abstract}
The paper attempts to explore the impact of Islam on the socio-political structure of Mandara Sultanate. It gives insight into how Islam penetrated into the social and political structure of the Sultanate. The paper utilized mostly the secondary source of data and guided by the evolutionary theory. Among the findings are, deities and shrines played prominent role before the advent of Islam and today, festivals like Idil-Al-Fitr, Adha and Maulid-Nabiy replaced the harvest and rainfall festivals in the area. The paper concluded that Islam has impacted positively on the lives of the people in the area as Islam has become a dominant religion in the Mandara Sultanate in Borno State.
\end{abstract}

Keywords: Mandara Sultanate; Socio-Political Structure; Islam.

Cite This Article: Dr Dani Mamman, and Dr S. Y. Ibrahim. (2017). "THE IMPACT OF ISLAM ON SOCIO-POLITICAL STRUCTURE OF MANDARA SULTANATE: AN OVERVIEW." International Journal of Research - Granthaalayah, 5(7), 179-186. https://doi.org/10.29121/granthaalayah.v5.i7.2017.2119.

\section{Introduction}

Mandara is the Kanuri corruption of the term Wandala which is how the people who inhabit the plain to the north of the chain of states of the North-east, the flooded plains of the Charilogone in the east, the rocks of Binder in the south-east, the Mandara mountain in the south and south-west and the Yedzaram valley in the West. Mandara emerged as a state by the early $16^{\text {th }}$ Century through the fusion of the three different groups, each of which contributed to the foundation of the Mandara kingdom. These groups are the Massa hunters living in the north-west of Cameroon, Maya who were said to be descendants of the legendary and the Gamergu farmers who migrated from the west.

\subsection{The Origin of the Mandara Sultanate}

The kingdom had been well established by the $16^{\text {th }}$ Century. And the political system that developed consisted of an elaborate court that came to consist of about 78 title holders and other 
functionaries, headed by Thikse. And as this has been the case with most of the state empires, the office of Thikse is also hereditary. The historical legends of most ethnic groups in the Lake Chad Basin seem to emphasize similarities in their origin. That is coming from the East and so have same historical legend with the Mandara brethren. Kerawa is regarded as the centre of the Mandara people and the Mandara land was at one time ruled by Queen Sugda who succeeded her husband after his death. Kerawa dominated all other villages nearby and the Wandala ruled the Mandara dynasty. The name of the Mandara leader was called Thlikse (Owner of). The other village chiefs became united under the centralized chiefdom with Kerawa as the Headquarters of Mandara land (Birma, 1996).

According to Barkindo (1989), the Thlikse ( the spiritual leader) was recognized for his military might, economic and cultural values. Mandara expanded further southwards and eventually formed the Mandara Sultanate where the Gamergu and neighbouring people continued to identify with the Thlikse as the sacred king. Most of the well known centers of worship were brought under the control of Thlikse. These centers were, Ishaga- Kewe, the stone cult of Kerawa, the Kingiro Lake etc.

\section{Economic Activities}

There were archaeological discoveries in the sandy areas of Gammergu which according to Connah(1983) could have been as far as the $15^{\text {th }}$ Century but was abandoned around the $18^{\text {th }}$ Century. Barkindo (1989) on the other hand observed that Gamergu town appeared to have been big and surrounded by a wall and a ditch and the archaeological materials discovered on the surface of the wall suggested that Gamergu was built on a more ancient settlement and the people there worked in iron which was used for both tools and decorations. They were also possibly farmers because fragments of grind stones and pieces of grinders were found.

From the preceding paragraph therefore, economically, the kingdom was viable. Forinstance, there was a great traffic in iron and "Nicoli" Stones. The principal trading towns were Kerawa, Mokolo and Mora. The Teda supplied them with North African products. Logon traders brought pots and fish in exchange for iron implements and foodstuff. Furthermore, the Kanuri traders brought cotton and indigo. The area around Gamboru was noted for cotton and indigo production in exchange for iron bar and slaves. Raiding for slaves was the order of the day. Slaves were not captured in the course of the Jihad, but rather through the collusion between Mandara and the "Kirdiya" (Pagans). This form of trade in human probably made up a large proportion of the commerce taking place in the area. This in most cases resulted in collusion between the Mandara and Kirdiya deliberately. For instance, the Pullo speaking of Vame Mbrem lineage of Dibilikwer, living on Miyaw ridge north of Mayo Plata were eliminated after their depredations on neighbouring groups became too extreme, the Plata or Pullo lineage coordinated attack on the Mandara among others. Many were killed and others sold into slavery and only very few were able to escape.

\section{Political and Social Organization}

The beginning of the $18^{\text {th }}$ Century saw the acceptance of Islam as a state religion by Thikse Bukar Aji (1715-1737A) that witnessed the significant changes in Mandara courts. The rulers 
came to be styled as Mai after the manner of Borno. In the same vein, it saw the introduction of the office of the Gama variant with Borno's Kaigama. Islamic institutions like mosques and Qur'anic Schools, Alkali, Talba (Scribe) Liman (Iman) were also instituted. As Barkindo puts; This seems to be the time when Mandara came clearly within the sphere of influence of Borno. Mandara reached its apogee during the reign of Mai Bukar (Gyama C. 1773-1829). Mandara fell under the control of the imperial Germany by the Anglo-Germany treaty of July/August 1886 (German Kamerun in 1902). The kingdom remained undivided and conquered up to the coming of the colonialists.

Wandala society is very different from that of its neighbouring tribes. Traditionally, the Mandara state in many ways is similar to a number of other Muslim Sudanic states where the Government rules by hereditary monarchy. In the Mandara Sultanate, the Thikse is the head. There seemed to be quite decentralization in governance until the $17^{\text {th }}$ and later part of $18^{\text {th }}$ Centuries.

The Makajis who were the governors of the four provinces of the state, had considerable independence.

In the social sphere, the Mandara social organization after the introduction of Islam in the state did not resemble that of their Kirdis (Montagnard neighbours). Partrilineages did not exist and ascendancy was reckoned by both parents. Families were rarely polygamous and most often live together in nucleated villages which also contained guest-houses for foreigners (traders and scholars). In keeping with Muslim tenets, sex roles were much more rigidly defined among the Mandara after the introduction of Islam than before. Men took care of the activities outside the homes, such as farming, while women were house wives and mothers. The Mandaras are Sunni Muslims and have theoretically been so since $18^{\text {th }}$ Century. The Muslim festivals of Idil-fitr, Idil Adha, Maulid Nabiy are also celebrated replacing the pre-Islamic festivals of harvests and rainfall.

The practicing of smiths, barbers and hunters are very characteristics of Wandala culture before Islam. So also the belief in spirit and it scarcely needs comment. The Pre-Islamic Mandara culture believed in the spirit called Shatana (Shatane, singular), that whenever a woman loses a child, then a sorcerer is consulted and in most cases would tell them that the mother was possessed by evil spirit and rites are performed to dispel this evil spirit. Then parents would also name their child Shatane i.e. spirit. In the same regard, the sorcerer may also tell them that it is a spirit in animal form like monkey (Vrayre), bush cow (Madva). All these practices, with the introduction of Islam in Mandara Sultanate gradually faded away.

They invoke nothing but female deities beside him (Allah) they invoke nothing but Satan, a persistent rebel Allah cursed him and he (Satan) said: I will take an appointed portion of your slaves: verily I will mislead them and surely. I will cause in them false desires and certainly I will order them to slit the ears of cattle and indeed I will order them to change the nature created by Allah (119-110).

The presence of ancestors and all their participation in the day-day affairs of the community were vividly clear in the affairs of women which were reminiscent of the Pre- Islamic practices such as beer was poured on the ground as the shares of the ancestors. The practice of pouring water on the ground before drinking to replace the pouring of beer was not abandoned until the 
last 30-40 years ago. The practices persisted in the villages and were never abandoned by the hill dwellers. This was because, Islam was only practiced on the plain and never presented to the hill dwellers until recently when efforts were made by the late Sardauna of Sokoto, Sir Ahmadu Bello who attempted to Islamize Gwoza hill dwellers. Also, while Sheikh Zahoor Ahmed Malik, an itinerant "Dawa'ah" activist, also engaged in the Guduf hills Dawa'ah in 1992. Sheikh Zahoor was received warmly by Abubakar Willa. They converted up to about 250 from the villages of Khirke, Kunibe, Ghada and Ghuffure. He lectured and this was translated by Muhammed Dauda into Guduf language. Sheik Zahoor emerged and trained Dauda and other sons of Guduf. Zahoor also engaged the Unity Da'awah group to concentrate on the said area at the hill top while he was handling the Kurana Bassa Islamic School at the foothill. Also, the University of Maiduguri Da'awah group led by Sheikh Goni Muhammad Gabchiya embarked on the Islamization of the hill dwellers. It began with the Guduf, Da'awah School in 1992, in order to facilitate the programme. Teachers were employed and posted to the hills to preach and teach Islam.

Musa Ahmadu was said to have been engaged as one of the pioneering preachers around the Guduf area, while Mallam Musa Buba Barawa engaged himself around Guduf Bubayawa. He initially met only few people, around 7 Muslims when he started preaching, that made some preachers to have interest around the areas. With these encouragements, Abbas Raha, the Chiroma of Gwoza requested Mallam Musa to relocate to Guduf Nagadiyo. Thus, in April 1970, Mallam Adamu Saidu Al-Murshid, Secretary of Jama'at Nasirul Islam (J.N.I) in Gwoza sent Mallam Musa a commendation letter. And that also mandated him to preach beyond the Guduf hill areas. In 1980, Mallam Buba Iya was posted to Guduf. Buba Iya organized an evening lesson in front of the Lawan's palace. What started with seven members increased to a class of forty two pupils.

\section{How Islam Developed among the Gwoza Hill Dwellers}

Muslim Students' Society, Gwoza Branch made some efforts to propagate Islam in the area. The first chairman was Umar Bukar Bulamami and the Secretary was Mallam Yusuf Wassa. Yusuf Wassa has been a very active "Da'awah" member while he was an Arabic teacher at Kerawa 'A' Primary School. Their efforts led to conversion of many pagans to Islam. They have achieved considerable success in Islamizing Gwoza hill dwellers, especially the Guduf.

Similarly, the Jam'atu Izalatu Bid'a wa Ikamatus Sunnah also helped (JIBWIS) in Islamization of the Gwoza hill dwellers. The Gwoza Branch of JIBWIS was said to have really educated the people about their religious duties as well as on the hill top. In the same process, a four man 'Da'awa' delegation was appointed in November, 1997 by Sheikh Ibrahim Saleh Al Hussain, leader of "Jam'alAnnahadah Al-Islamiyya in Maiduguri to participate in the struggle. Other individual scholars at Mora, Meme, Kerawa and Mada contributed in resettling the people of the hills and converted them to Islam. The authors opined that, perhaps, what the leaders of the Mandara Sultanate realized in the $17^{\text {th }}$ and early part of the $18^{\text {th }}$ Century to accept Islam as a means to solving their socio political problems had never been accepted or realized by the leaders of the hills. This probably accounted for the negligible population of the Muslims among of the hill people. Up to the present level of Islam acceptance, the Maffa, Podkwe, Chikide and Kirdi Mora are mostly pagans. 
The political changes are by far more vigorous and dynamic. The Mandara Sultanate adopted Islam as a state religion during the reign of Thikse Bukar Aji (1715-1737) who took the additional title of Sultan. The court was remodeled in accordance with other Muslim states of Central Sudan, especially Borno. There was an elaborate court organized including entertainers and attendants. They became absolute rulers, at least in the areas they presided over. In fact the process of nomination and installation of leaders greatly changed with the introduction of Islam. Most of the ceremonies, at least the practice of the cutting of the ears of all possible rival princes once the successor had been chosen stopped so that they could never become a Thikse stopped immediately. A similar practice was with Muhammad El-Amin (I749 -1784) whose rule was overlapped with Thikse Madi Makkiya. (1737-1751), Bladi (1757 1773) and Thikse Bukar-aJama (1773-1828).

It should be noted that in spite of the efforts made to Islamize the area, the few who did not accept continued with their former practices of worshiping of deities and performance of rituals at designated shrines likeGathazuli (a stone deity) at Kerawa and the Thulli Vokoke a tree at Vokethe within the Kerawa area, also the river Logone and river Chari along Chad and Cameroon border, all had preeminence in the Pre-Islamic culture of Mandara. These shrines were visited and sacrifices made in times of calamities or famine. These poems are recited at the above mentioned shrines:

$\begin{array}{ll}\text { Ya Umataruwa } & \text { Oh! My Umate } \\ \text { Zalke } & \text { Zalke } \\ \text { Ya Bukararuwa } & \text { Oh! My Bukar } \\ \text { Zalke } & \text { Zalke } \\ \text { Yadum haye logone } & \text { I went to river Logone } \\ \text { Bienka yawankwa } & \text { I did not get water } \\ \text { Yadum haye chari } & \text { I went to river Shari } \\ \text { Bienka yawankwa } & \text { I did not get water }\end{array}$

The above songs are sung when there is acute shortage of rainfall. It is believed that God will provide rainfall through these special prayers and visiting of these ritual places. However, Islam has emphatically stated how rain prayer (Al Istisqa') is done. It was related by Ibn Abbas (may Allah be pleased with them both) that:

The Prophet (PBUH) went out (to offer the Istisqa'a prayer) in a state of humbleness, dressed in old clothes, in a submissive manner, walking slowly, entreating Allah (in humility) and prayed two rak'at as he prayed the 'Id prayer, but did not deliver a similar sermon (like the one he used to convey on the 'Id day). 'Related by the Imams. AtTirmidhi, Abu 'Awanah and Ibri Hibban sorted it as Sahih.

Similarly, on the authority of 'A' ishah (May Allah be pleased with her) who said,

"The people complained to the Messenger of Allah (PBUH) about the lack of rain, so he ordered for a rostrum to be established for him in the place of prayer, and thus it became ready for him. He then assigned a day for the people to get out and he came out on that when the sun had just become visible. He sat down the rostrum, said Takbir (Allah is the 
Greatest) and praised Allah. Then he said, "You have complained of drought in your areas, but Allah has ordered you to entreat Him in supplication and he has promised respond to your prayers," then he said "All praise Allah, the compassionate, the Merciful, and the only master of the day of Judgment. There is no god but Allah Who does what He wills. 'O Allah, there is no God but You! You are the self-sufficient and we are the needy. Send down rain upon us and make it a means of strength and satisfaction for us. He then raised his hands and kept doing this till the whiteness of his armpits could be witnessed. Then, he turned his back to the people and turned his garment around, while raising his hands then he faced the people, dismounted the rostrum and prayed two rak'at. Afterwards, Allah, the Almighty sent a cloud that emitted thunder and lightning, followed by rain." Related by Abu Dawud who said that its transmission was good.

Furthermore, on the authority of Anas (may Allah be pleased with him), it is related that a man got into the mosque on Friday while the prophet (PBUH) was standing and conveying the sermon. The man said,

O Messenger of Allah, our wealth has been destroyed and we no longer have any transport. Supplicate to Allah the Exalted for us to relieve us by sending rain on us. The prophet $(P B U H)$ raised his hands and said, "O Allah, give us rain. O Allah, give us rain, OAllah, give us rain, etc.

Umar Ibn Al-Khattab used to request ibn Abbas to supplicate for rain prayer as reported by Anas (may Allah be pleased with him), "Umar Ibn Al-Khattab (may Allah be pleased with him) used to turn to Al-Abbas Ibn Abdul-Mutalib when drought befell asking him to supplicate to Allah to send rain, and he said:

"O Allah! We used to supplicate to you for rain through our prophet, and You responded (by sending rain), and now we entreat You through the Prophet's uncle, so bless us with rain. Therefore they were given rain, (Bukhari).

Thus, the impact of Islam on the socio-political life of Mandara people in particular and the state in general cannot be over emphasized. The state adopted Islam as a state religion; scholars came to play a great role in advising the Thikse on day to day affairs of the state. Deities and shrines no longer played prominent role in offering sacrifices, or being consulted in period of famine and calamites. Islamic festivals like Idil-Al-Fitr, Adha and Maulid-Nabiy replaced the harvest and rainfall festivals.

\section{System of Administration (the Malamah/ Council of State)}

The Islamic scholars assumed positions of prominence in the Sultanate after the adoption of Islam as a state religion and six of these scholars have religious titles. These titles are

1) El-Kali (Judge) He judges in court according to Qur'an and the Sunnah of the Holy Prophet.

2) Liman-a-Bala: He performs all the Islamic festivals and presides over prayers like rain prayer in time of calamity like droughts or famine.

3) Liman-a-Thma: he leads in Friday Prayers. 
4) Liman a-Hudqa (palace Imam) he leads prayers inside the palace. He also teaches members of the royal family. With the introduction of Islam as a state religion in Mandara, succession to the throne is primarily merited through the ability of the prince to commit the Qur'an into memory. Thus, the princesses engaged in the memorization of the Qur'an inside the palace. Thus, till date, no Mandara prince would become Thikse unless he has memorized the Qur'an. That's why a special Imam that engages in teaching the members of the royal family is attached to the palace.

5) Talba (Scribe) He serves as a scribe to Thikse. He also judges in Hudqa (palace).

6) Shettima- he lives with the Malumah. He plays a great role in selecting and determining who amongst the scholar is knowledgeable and plays a significant role in the Islamization of the pagans.

The Malumaha were consulted by the Thikse on matters of importance and their advice sought.

\section{Theoretical Framework}

This type of work requires a guide and so is situated within the context of the Evolutionary Theory. The theory is also sometimes called the historical theory (Appadorai, 1975:37). According the theory, a state developed out of the early primitive family in which one person was the head. Over the years, the original family unit became network families on clan. Eventually, more clans grouped together to create a tribe. Once these nomadic tribes began to settle and develop, the state was born.

The assumption here is that, the state is neither as a divine institution nor a deliberate human contrivance; rather it is a state coming into existence as a result of natural evolution. In this case, common worship is an element in the welding together of families and tribes. Furthermore, the primitive man had faith in the existence of spirits and finally, war and conquest helped to give the mark of territoriality to the state.

From the above mentioned assumptions of the evolutionary theory, it is relevant when applied to the origin, existence and development of the Mandara Sultanate, hence its adoption. The Mandara Sultanate evolved naturally in spite of the challenges it went through.

\section{Findings}

1) The Mandara Sultanate had gone through serious struggles in the past and perhaps is the more reason why the area stands out in the Gwoza Emirate in terms of resourcefulness such as, devotion to Islamic religion, education and wealth.

2) The average Mandara is not lazy. This could be because of their way of life from the beginning.

3) A lot of individuals and groups played significant role in the process of socializing the people.

4) The sultanate had its own political arrangement before the advent of colonialism and eventual ascendance of the democracy in Nigeria. 


\section{Conclusion}

The paper concluded by acknowledging the fact that, Islamic religion has positively impacted on the lives of the Mandara Sultanate economically, politically and socially. Despite the challenges it went through, it has come to stay as a sultanate (nation) as advocated by the Evolutionary Theory.

\section{References}

[1] Appadorai, A. (1975) The Substance of Politics, Oxford University Press.

[2] Barkindo, "B. M, (1989) The Sultanate of Mandara to 1902, Franz Stainer", Verlag.

[3] Birma, M.D. (1996) The Gamargu: Their Environment and Early History from Earliest Time to Present Time, Department of History, University of Maiduguri (Unpublished).

[4] Connah, G.(1983) Some Contribuions of Archaeology to the History of Borno. In The History of Pre- Colonial Borno, B. Usman and N.Alkali (eds) Zariathe Northern Nigeria Publishing Company.

[5] Mamman, D. (2009) A story of the Impact of Colonialism on Mandara Sultanate, Ph.D Thesis (Unpublished)

[6] Mamman,D. (1989) "The Emergence of Islamic Scholars in Mandara”. An Undergraduat project Submitted to the Department of Arabic and Islamic Studies,Unimaid(Unpublished).

[7] Scott, M. (1990) The process of Montagnard ethnogenetics in the Northern Mandara Mountains Cameroun, Calgry.

[8] An Interview with Malam Abba Liman Maha aged 68 (Chief Imam of Kirawa, Gwoza LGA) on 20/1/2010 at his residence.

[9] An Interview with Liman Made, aged 75, an Islamic Scholar at his residence in Mora (Republic of Cameroon) on 12/2/2010.

*Corresponding author.

E-mail address: danimamman@ gmail.com 